\title{
Peningkatan Produktivitas Dan Kinerja Lingkungan Menggunakan Metode Green Productivity
}

\author{
Hersandi Hamdan Pratama \\ Jurusan Teknik Industri, Fakultas Teknik, Universitas Muhammadiyah Malang \\ Jl. Raya Tlogomas No. 246, Malang, Jawa Timur 65144 \\ Surel: hersandihamdan@gmail.com
}

\begin{abstract}
Every company certainly wants to increase their productivity, such as by increasing the amount of production. However, as goes by production, important to notice the aspects surrounding of the environment performance. Therefore we need a method to improve productivity and environmental performance simultaneously. The purpose of this study is to identify factors that affect the productivity and environmental performance, and provide suggestions using the method of Green Productivity improvements based on the highest value of Green Productivity Index. Based on research in $P G$ Kebon Agung there are two alternative solutions that improve productivity and environmental performance, but the GPI of alternative 2 is bigger than ternative 1 which is 4,47. The alternative is additional outlet capacity at waste treatment plants. This solution provides increased productivity, where the initial productivity of $136.045 \%$ to $136.05 \%$. With the implementation of alternative solutions can improve EPI index up 0.32 so to give an increase in the Index EPI (Environmental Performance Indicator) from 0.46 became 0.78
\end{abstract}

Keywords: Green Productivity, Productivity, Environmental Performance, EPI, PG Kebon Agung

\begin{abstract}
Abstrak
Setiap perusahaan pasti menginginkan untuk meningkatkan produktivitas, salah satunya dengan meningkatkan jumlah produksinya. Sejalan dengan peningkatan produksi, perlu diperhatikan aspek kinerja lingkungan disekitarnya. Diperlukan sebuah metode guna meningkatkan produktivitas dan kinerja lingkungan secara bersamaan. Tujuan makalah ini yaitu mengidentifikasi faktor-faktor yang berpengaruh terhadap produktivitas dan kinerja lingkungan, serta memberikan usulan perbaikan menggunakan metode Green Productivity berdasarkan nilai Green Productivity Index tertinggi. Makalah ini dilaksanakan di perusahaan PG Kebon Agung dengan menggunakan 2 alternatif solusi yang dapat meningkatkan produktivitas dan kinerja lingkungan, namun alternatif ke 2 menghasilkan nilai Green Productivity Index tertinggi yaitu sebesar 4,47. Alternatif tersebut berupa penambahan kapasitas outlet pada unit pengolahan limbah. Solusi ini memberikan peningkatan produktivitas, dimana produktivitas awal sebesar 136,045\% menjadi 136,05\%. Penerapan alternatif solusi ini dapat meningkatkan indeks EPI hingga 0,32 sehinga memberikan peningkatan pada Index EPI (Environmental Performance Indicator) dari 0,46 menjadi 0,78.
\end{abstract}

Kata Kunci: Green Productivity, Produktivitas, Kinerja Lingkungan, EPI, PG Kebon Agung.

\section{Pendahuluan}

Produktivitas merupakan satu hal yang sangat penting bagi suatu perusahaan sebagai salah satu cara untuk memantau kinerja produksinya[1]. Sejalan dengan adanya peningkatan produksi, ternyata timbul banyak permasalahan lingkungan 
disekitarnya[2]. Permasalahan disebabkan karena proses produksi seringkali mengakibatkan pembuangan material dan energi yang akan membebani lingkungan, padahal proses produksi yang baik tidak hanya memperhatikan keamanan dan efek samping dari limbah sisa produksi, namun juga berusaha mereduksi limbah buangan yang dihasilkan[3]. Sangat penting bagi perusahaan untuk memperhatikan aspek-aspek lingkungan dalam operasi produksi yang dilaksanakan agar dapat menciptakan keserasian dengan lingkungan disekitarnya[4].

Pendekatan yang tepat untuk membantu perusahaan agar mampu meningkatkan produktivitas dan kinerja lingkungan adalah dengan menerapkan metode green productivity[5]. Dimulai dengan menganalisis input, proses dan outputnya, green productivity diharapkan bisa mereduksi waste dari proses produksi serta mampu mengurangi penggunaan sumber daya dan energi material yang berdampak pada pengurangan pemborosan maka akan lebih efektif dalam proses kerja yang dilakukan[6].

Tujuan makalah ini yaitu untuk mengetahui tingkat produktivitas dan kinerja lingkungan di perusahaan. Sehingga dapat mengidentifikasi aspek permasalahan yang berpengaruh terhadap produktivitas dan kinerja lingkungan serta memberikan solusi terhadap permasalahan untuk meningkatkan produktivitas dan kinerja lingkungan dengan mempertimbangkan Green Productivity Index.

Dengan implementasi Green Productivity (GP) diharapkan bisa meningkatkan produktivitas serta menghasilkan capaian lingkungan didalam penggunaan sumber daya dan energi yang lebih sedikit sehingga akan berdampak pada pengurangan pemborosan sehingga akan lebih efektif dalam proses kerja yang dilakukan. Implementasi Green Productivity (GP) juga memungkinkan terjadinya eco-efficiency yang ke depannya akan mengarah pada sustainable development[7].

\section{Metode Penelitian}

Pengambilan data pada makalah ini dilakukan melalui delapan tahapan yaitu tahap pendahuluan, tahap identifikasi, pengukuran, identifikasi masalah, menyusun alternatif, usulan perbaikan, analisis dan tahap penarikan kesimpulan. Pada tahap pendahuluan yang merupakan langkah awal dengan melakukan studi lapangan dan studi pustaka. Studi lapangan bertujuan mengetahui kondisi riil perusahaan khususnya proses yang banyak menghasilkan limbah. Setelah memperoleh gambaran dari survei awal dan mengetahui kendala-kendala yang dihadapi oleh perusahaan, maka dilakukan studi pustaka untuk mendukung makalah yang akan dilakukan sehingga makalah mempunyai dasar teori yang terarah dan memberikan hasil pemecahan yang optimal.

Pada tahapan identifikasi akan dilakukan perumusan masalah dan pengumpulan data, baik data primer maupun data sekunder. Setelah itu akan dilanjutkan dengan tahap pengukuran yang bertujuan untuk mengetahui tingkat produktivitas dan kinerja lingkungan yang telah dicapai perusahaan selama ini. Selain itu hasil pengukuran produktivitas dan kinerja lingkungan yang telah dilakukan akan dijadikan acuan untuk estimasi peningkatan produktivitas dan kinerja lingkungan apabila metode green productivity dilaksanakan. Pengukuran produktivitas dihitung dengan membagi output total dengan input total[8].

Tahapan identifikasi masalah dan penyebab merupakan tahapan kedua metodologi green productivity yaitu Planning. Setelah mendapatkan informasi yang dibutuhkan melalui kegiatan pengamatan, wawancara dengan sumber yang ahli pada bidangnya, pengambilan data perusahaan, pengukuran produktivitas dan kinerja 
lingkungan, maka dapat diidentifikasi permasalahan yang berkaitan dengan green productivity dengan metode diagram Ishikawa[9].

Tahapan menyusun alternatif solusi merupakan tahapan ketiga dalam metodologi Green Productivity yaitu generation and evaluation. Pada tahap ini pemakalah berupaya memecahkan masalah dengan menyusun alternatif-alternatif yang memungkinkan untuk diterapkannya metode green productivity. Alternatif-alternatif tersebut dapat berupa minimasi limbah ataupun hal lainnya yang nantinya dapat meningkatkan produktivitas dan mengurangi dampak lingkungan.

Perbandingan antara Green Productivity Index alternatif dengan Green Productivity Index kondisi awal perusahaan dilakukan pada tahap sebelumnya. Apabila Green Productivity Index alternatif lebih besar rasionya daripada Green Productivity Index awal perusahaan, maka dapat dilanjukan dengan menetapkan alternatif terpilih sebagai usulan perbaikan. Tahapan ini disebut dengan tahapan usulan perbaikan.

Pada tahapan analisa dan pembahasan menguraikan analisa hasil pengukuran produktivitas, perhitungan indeks Environmental Performance Indicator (EPI), analisa permasalahan, penyusunan alternatif solusi, perhitungan nilai deret seragam dan pemilihan alternatif solusi.

Tahapan yang terahir adalah tahapan kesimpulan dan saran. Pada tahap ini didapatkan hasil berdasarkan pengolahan, analisa dan interpretasi yang dilakukan. Maka didapatkan kesimpulan dan juga diajukan beberapa saran yang nantinya menunjang kontinuitas pelaksanaan alternatif solusi yang terpilih.

\section{Hasil dan Pembahasan}

Makalah disusun dengan lokasi di Pabrik Gula Kebon Agung terletak di Desa Kebon Agung, Kecamatan Pakisaji, Kabupaten Malang, Propinsi Jawa Timur, pada ketinggian $\pm 480 \mathrm{~m}$ diatas permukaan laut. Bentuk topografinya berupa lahan datar berbukit yang berada di lereng Gunung Kawi sebelah Barat. Limbah industri yang dihasilkan berupa limbah padat, limbah cair dan limbah gas. Pada makalah ini lebih memfokuskan pada limbah cair yang dihasilkan PG Kebon Agung berasal dari air pendingin, limbah masakan, air cucian mesin.

\subsection{Perhitungan Produktivitas}

Sejak awal perkembangan hingga kini produktivitas memiliki beragam pengertian dan telah banyak dideskripsikan oleh banyak peneliti. Secara umum produktivitas diartikan sebagai hubungan antara keluaran (output) dengan masukan (input). Produktivitas adalah ukuran efisiensi produktif suatu pembanding antara hasil keluaran dan masukan[10]. Pengukuran produktivitas dihitung dengan membagi output total dengan input total. Output adalah hasil data total penjualan, sedangkan input diperoleh dari biaya material yang dikeluarkan, biaya tenaga kerja, biaya penggunaan energi, biaya air, serta biaya pengolahan limbah. Perhitungan tingkat produktivitas total perusahaan menggunakan persamaan sebagai berikut:

$$
\text { Indeks produktivitas total }=\frac{\text { total Output }}{\text { total Input }}
$$

Dengan menggunakan rumus 1 maka nilai produktivitas perusahaan pada periode 2012-2015 dapat dilihat sebagai berikut: 
Tabel 1 Produktivitas Perusahaan

\begin{tabular}{ccc}
\hline No & Tahun & Produktivitas \\
\hline 1 & 2012 & $128.57 \%$ \\
2 & 2013 & $132.15 \%$ \\
3 & 2014 & $129.61 \%$ \\
4 & 2015 & $136.04 \%$ \\
\hline
\end{tabular}

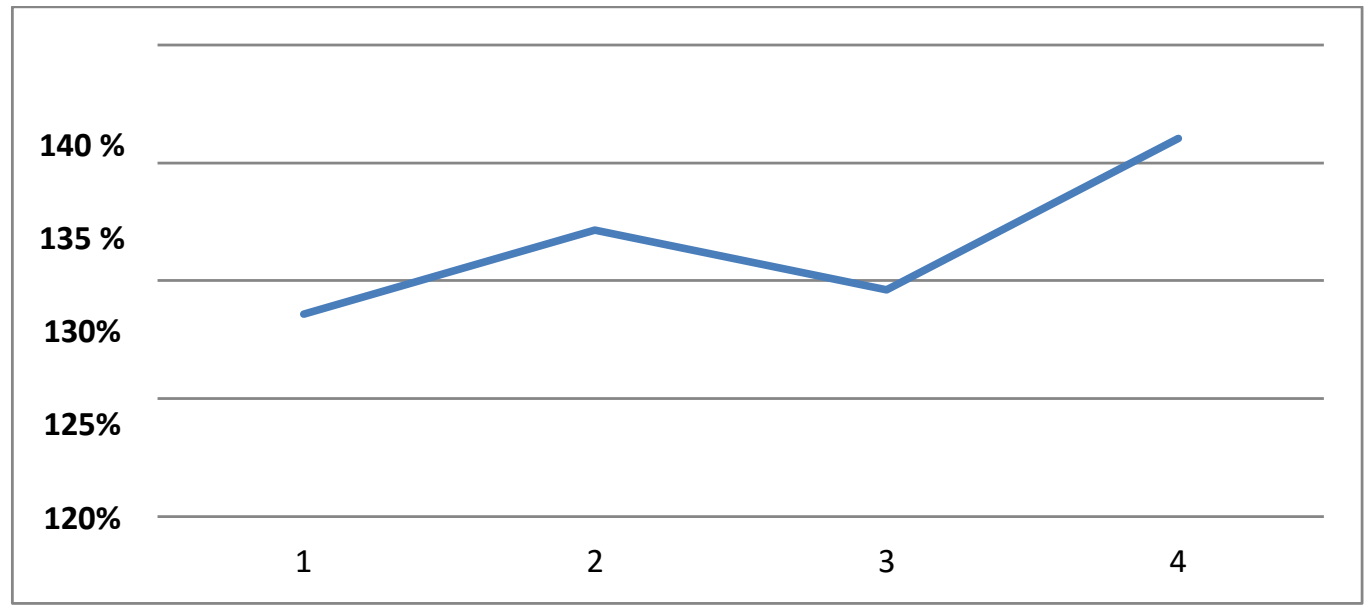

Gambar 1 Grafik Nilai Produktivitas Periode 2012-2015

Dari gambar 1 diketahui bahwa produktivitas perusahaan diatas 100\%. Dengan kata lain produktivitas sudah cukup baik dan memiliki pola trend meningkat. Rata-rata produktivitasnya adalah 136,045\%.

\subsection{Perhitungan Kinerja Lingkungan}

Environmental performance adalah kinerja perusahaan dalam menciptakan lingkungan yang baik. Pengukuran kinerja lingkungan merupakan bagian penting dari sistem manajemen lingkungan. Hal tersebut merupakan ukuran hasil dari sistem manajemen lingkungan yang diberikan terhadap perusahaan secara riil dan kongkrit. Kinerja lingkungan adalah hasil yang dapat diukur dari sistem manajemen lingkungan, yang terkait dengan kontrol aspek-aspek lingkungannya. Pengkajian kinerja lingkungan didasarkan pada kebijakan lingkungan, sasaran lingkungan dan target lingkungan (ISO 14004, dari ISO 14001). Sehingga kinerja lingkungan dapat dikatakan sebagai kinerja perusahaan untuk menciptakan lingkungan yang hijau (green). Untuk menghitung kinerja lingkungan perusahaan maka digunakan Environmental performance indicator (EPI).

Environmental performance indicator (EPI) dapat diartikan sebagai parameter yang didasarkan pada jumlah yang diteliti atau dihitung. Sebuah indikator lingkungan merupakan suatu hal yang diperkirakan dapat menggambarkan berbagai dampak dari suatu aktivitas pada lingkungan dan usaha untuk mereduksinya. EPI menggambarkan efisiensi lingkungan dari proses produksi dengan melibatkan jumlah input dan output. Indikator performasi dapat menggabungkan indikator sistem, guna menggambarkan usaha perbaikan oleh sebuah unit proses untuk mengurai dampak lingkungannya. Indeks EPI dapat dihitung menggunakan rumusan:

$$
\text { Indeks } E P I=\Sigma i-1^{k} W i P i
$$


Dimana $\mathrm{k}$ adalah jumlah kriteria limbah yang diajukan dan Wi adalah bobot dari masing-masing kriteria. Bobot ini diperoleh melalui penyebaran kuisioner kepada para ahli kimia lingkungan. Bobot tersebut berdasarkan parameter kesehatan manusia dan keseimbangan lingkungan. Kedua parameter tersebut diberikan prosentase yang sama sebab apabila suatu zat kimia dinyatakan berbahaya bagi lingkungan, maka akan berbahaya bagi kesehatan masusia, karena manusia mengkonsumsi makanan dari hewan dan tumbuhan. Nilai Pi merupakan prosentase penyimpangan antara standar bapedal dengan hasil analisa perusahaan.

$$
\mathrm{Pi}=(\text { standart }- \text { analisa }) / \text { standart } x 100 \%
$$

Pembobotan pada perhitungan EPI didapatkan dari hasil wawancara dengan kepala departemen unit pengelolahan limbah PG Kebon Agung kemudian dihitung menggunakan AHP untuk mengetahui tingkat bahaya kandungan zat kimia pada limbah. Standart Baku Mutu diperoleh berdasarkan peraturan gubernur Jawa Timur No 52 Tahun 2015 tentang limbah cair. Data analisa merupakan hasil analisa limbah limbah cair pada tahun 2015 .

Tabel 2 Indek EPI

\begin{tabular}{lccccc}
\hline \multicolumn{1}{c}{ Parameter } & $\begin{array}{c}\text { Bobot } \\
(\mathrm{Wi})\end{array}$ & $\begin{array}{c}\text { Kadar } \\
\text { Maksimum }\end{array}$ & $\begin{array}{c}\text { Hasil } \\
\text { Analisa }\end{array}$ & $\begin{array}{c}\text { Penyimpangan } \\
(\mathrm{Pi})\end{array}$ & $\begin{array}{c}\text { Indeks EPI } \\
(\text { WixPi })\end{array}$ \\
\hline $\mathrm{pH}$ & 0.27 & $6-9$ & 7.90 & $100 \%$ & 0,27 \\
BOD 5 (mg/l) & 0.22 & 60 & 26.40 & $56 \%$ & 0,121 \\
COD (mg/l) & 0.15 & 100 & 60.62 & $39 \%$ & 0,059 \\
TSS (mg/l) & 0.13 & 50 & 9.00 & $82 \%$ & 0,107 \\
Sulfida (mg/l) & 0.09 & 0.5 & 0.01 & $98 \%$ & 0,085 \\
$\begin{array}{l}\text { Minyak dan } \\
\text { Lemak (mg/l) }\end{array}$ & 0.07 & 5 & 1.90 & $62 \%$ & 0,044 \\
$\begin{array}{l}\text { Volume Limbah } \\
\left(\mathrm{m}^{3} / \text { tahun) }\right.\end{array}$ & 0.08 & $465.506,1$ & $417.172,2$ & $10 \%$ & 0,008 \\
& \multicolumn{5}{c}{ Index EPI Total } \\
\hline
\end{tabular}

Berdasarkan tabel 2, total indeks EPI PG Kebon Agung bernilai positif yaitu sebesar 0,69. Artinya secara umum kandungan zat-zat kimia dalam limbah telah memenuhi standar yang telah ditentukan. Nilai EPI berkisar antara 0 sampai dengan 1 . Semakin besar nilai EPI, maka semakin bagus kinerja lingkungan yang telah diterapkan di perusahaan. Penyimpangan (Pi) dapat dikatakan baik apabila persentasenya bernilai positif dan semakin besar.

\subsection{Identifikasi Masalah dan Penyebab}

Tool yang digunakan dalam mengidentifikasi masalah dan penyebab dari kurang maksimalnya produktivitas dan kinerja lingkungan pada perusahaan adalah diagram Ishikawa. Data yang digunakan diperoleh dari wawancara staf ahli di beberapa departemen yang ada di PG Kebon Agung.

Meskipun persentase produktivitas dan kinerja lingkungan sudah cukup baik, namun terdapat beberapa elemen pada proses produksi yang masih dapat ditingkatkan lagi untuk mendapatkan hasil yang lebih efektif dan efisien. Berdasarkan analisis 
perhitungan Indeks EPI, dapat diketahui bahwa volume limbah cair memerlukan tinjauan lebih lanjut karena sudah mendekati batas maksimal standart yang telah ditentukan, sehingga diperlukan diagram ishikawa guna menganalisa sebab dan akibat.

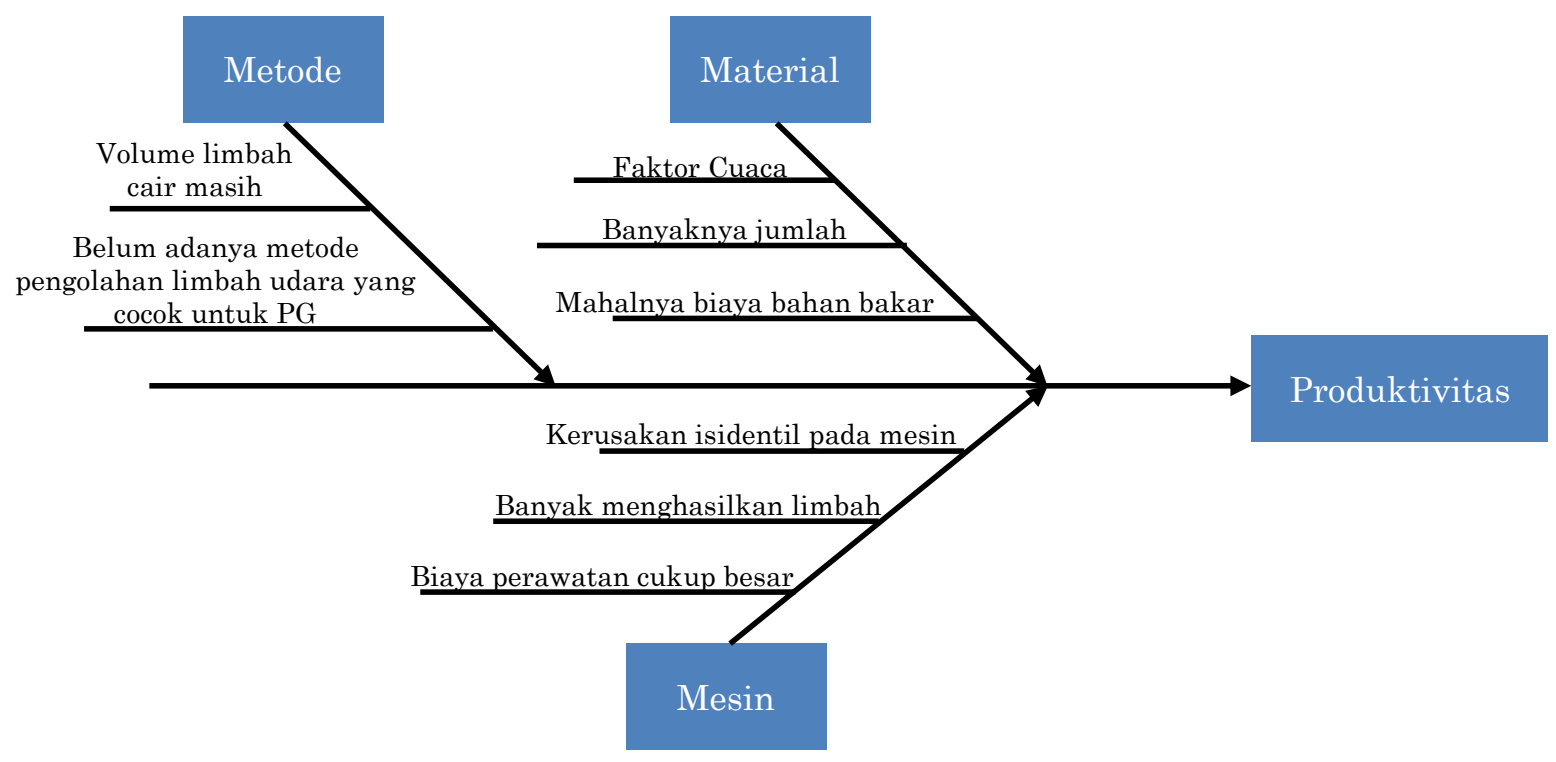

Gambar 2 Diagram Sebab Akibat Produktivitas

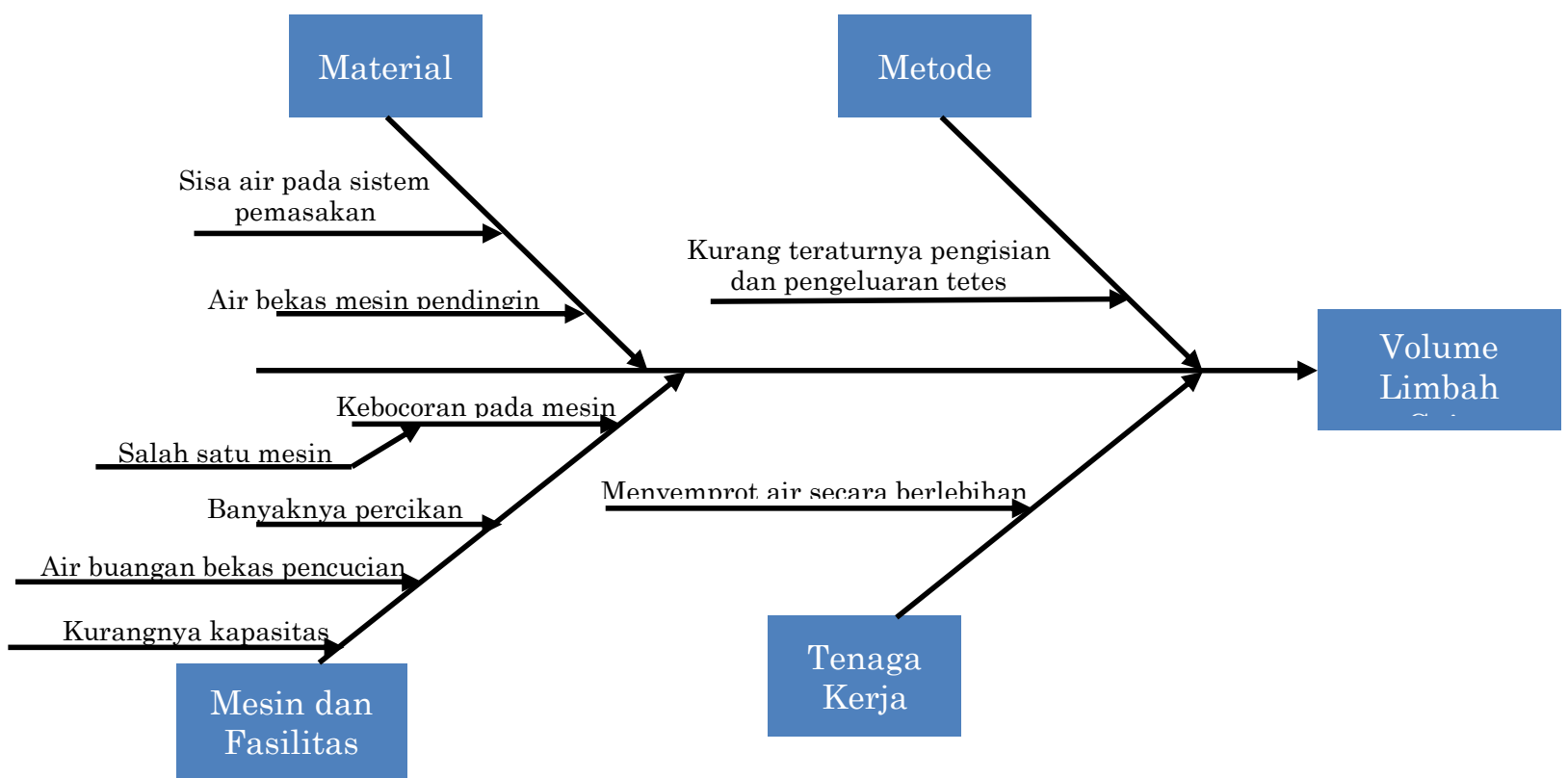

Gambar 3 Diagram Sebab Akibat Volume Limbah Cair

Dari 7 parameter zat-zat kimia, terdapat beberapa zat kimia yang mempunyai nilai penyimpangan (Pi) dan indeks EPI yang masih kecil, antara lain volume limbah sebesar 10\% dengan indeks EPI 0,008. Hal ini menunjukkan bahwa volume limbah memerlukan penanganan lebih lanjut karena mengindikasikan bahwa volume limbah sudah mendekati batas maksimal dan akan berbahaya bagi kesehatan lingkungan apabila telah melebihi batas maksimal. 
Dari segi produktivitas, faktor yang paling mempengaruhi adalah faktor cuaca, karena cuaca mempengaruhi jumlah tebu petani. Selain itu juga terdapat limbah cair yang masih banyak akibat kurang efisien dan efektif penggunaan air.

Dari diagram ishikawa juga dapat diketahui beberapa faktor masalah dan penyebab limbah cair. Masalah yang terjadi pada elemen material disebabkan oleh banyaknya limbah air pada stasiun masakan. Air di stasiun masakan digunakan untuk menyemprotkan gula A1 agar menjadi gula SHS. Limbah cair dari stasiun masakan memiliki suhu diatas $70^{\circ} \mathrm{C}$ dan telah terkontaminasi beberapa zat kimia. Selain dari stasiun masakan juga disebabkan oleh air bekas mesin pendingin. PG Kebon Agung memiliki beberapa mesin pendingin diantaranya kondensor Rotary Vacum Filter, kondensor evaporator, kondensor pan masakan, sublimator dan tobong belerang. Air mesin pendingin mengandung zat kimia dengan kadar yang sedikit. Zat kimia tersebut disebabkan karena sering kali air mesin pendingin tercemari oleh nira, blotong, ampas, larutan gula yang menyembur.

Kurang teraturnya pengisian dan pengeluaran tetes menjadi penyebab adanya permasalahan limbah cair pada elemen metode. Akibat dari kurang teraturnya pengisian dan pengeluaran tetes maka sering kali terjadi overload pada tangki penampungan tetes.

Pada elemen tenaga penyebabnya adalah menyemprot air secara berlebihan pada beberapa proses produksi. Air digunakan untuk menyemprot alat-alat yang panas pada stasiun penggilingan supaya dingin dan air bekas penyemprotan mesin ini merupakan limbah cair karena tidak tertutup kemungkinan tercampur dengan kotoran-kotoran mesin, minyak pelumas yang menetes karena kebocoran alat, serta tumpahan nira. Penggunaan air yang tidak terkontrol dan berlebihan mengakibatkan semakin banyaknya limbah cair dan semakin tidak efisien.

Salah satu penyebab dari masalah limbah cair yang ada pada elemen mesin adalah terjadi kebocoran pada pipa, tangki penampung dan mesin. Kebocoran tersebut sebagian besar disebabkan oleh mesin yang rusak. Listrik padam juga dapat mengakibatkan kebocoran, dikarenakan beberapa mesin mati dan pipa penyalur kelebihan kapasitas.

Percikan nira, stroop, dan minyak pelumas menyebabkan jumlah limbah cair bertambah. Mekipun jumlahnya tidak cukup banyak, namun cairan tersebut berubah menjadi limbah. Terlebih beberapa percikan mengandung zat kimia yang harus diolah pada unit pengelolaan limbah agar tidak membahayakan lingkungan ketika dialirkan kembali ke sungai sebagai tempat pembuangan akhir.

Pada proses penguapan terdapat 7 tangki evaporator, secara berkala ketujuh tangki evaporator ini dicuci untuk menghilangkan kotoran atau partikel-partikel yang menempel (kerak) pada dinding dan dasar tangki. Air bekas cucian ketujuh tangki, bekas pembersihan nira, kerak, dan coustic soda merupakan limbah yang diolah pada unit pengelolahan limbah cair di PG Kebon Agung. Selain itu limbah cair juga berasal dari buangan bekas cucian oli pelumas mesin, penyemprot sisa ampas nira yang terbuang, serta sisa penambahan bahan kimia. Di stasiun pemurnian juga dihasilkan limbah cair buangan berupa sisa pembersihan blotong, pembersihan ampas lembut sisa penyaringan, serta nira-nira yang berceceran.

Dengan kapasitas maksimal outlet yang hanya $40 \mathrm{~m}^{3} / \mathrm{jam}$, air limbah yang telah di recycle tidak mampu dialirkan seluruhnya ke kolam penampungan untuk di gunakan kembali pada proses produksi. Sedangkan air yang keluar dari bak clarifier sebesar 120 $\mathrm{m}^{3} /$ jam. Oleh karena itu, sisa dari limbah yang telah diolah harus dibuang ke Sungai Metro, sehingga perusahaan harus membeli air dari Jasa Tirta untuk menutupi kekurangan. Apabila perusahaan mampu memperbesar kapasitas outlet, maka biaya 
pembelian air untuk proses produksi bisa diminimalisir dengan adanya pengolahan kembali (reuse) limbah cair.

\subsection{Analisa Penyusunan Alternatif Solusi Alternatif 1}

Limbah cair yang dihasilkan oleh PG Kebon Agung paling banyak berasal dari mesin pendingin. Tidak hanya banyak mengasilkan limbah cair, mesin pendingin juga banyak membutuhkan air. Di tahun 2015, PG Kebon Agung memerlukan $149.600 \mathrm{~m}^{3}$ air untuk digunakan pada mesin pendingin. Sehingga perlu teknologi baru yang bisa mengurangi jumlah pemakaian air. Dengan begitu limbah yang dihasilkan pun juga ikut berkurang. Teknologi Biotray merupakan teknologi untuk meningkatkan efisiensi penggunaan air kondensor dengan memanfaatkan pengembangbiakan bakteri thermopholic di kolam cooling pound yang ditempatkan pada biotray. Biotray terpasang pada sarana pendingin dengan kerangka alumunium atau logam lain dan catridge mikoba BT55. Biotray bermanfaat bagi kelancaran proses, penghematan konsumsi air, dan memperlambat korosi pada pipa - pipa air serta pompa-pompa air. Biotray juga mampu mengurangi kandungan zat kimia sehingga air bekas limbah kondensor dapat digunakan kembali. Kebutuhan air kondensor dapat diturunkan hingga 50\%.

PG Kebon Agung memiliki 5 mesin kondensor yang berukuran besar di beberapa stasiun kerja. Sehingga dibutuhkan 5 biotray untuk mesin kondensor. Berikut adalah estimasi pengeluaran biaya:

Estimasi pengurangan debit air setelah diimplementasikan teknologi biotray pada mesin kondensor sebesar:

Penghematan :

$$
\begin{aligned}
& =50 \% \times \text { kebutuhan air mesin pendingin } \\
& =50 \% \times 149.600 \mathrm{~m}^{3} \\
& =74.800 \mathrm{~m}^{3}
\end{aligned}
$$

Dengan demikian didapatkan biaya penghematan per tahun sebesar

$$
\begin{aligned}
& =74.800 \mathrm{~m}^{3} \times \mathrm{Rp} 1.489 * \\
& =\operatorname{Rp} 111.377 .200
\end{aligned}
$$

*harga air pabrik Jasa Tirta 2015

Dengan mengimplementasikan alternatif 1 maka pemakaian air dapat berkurang menjadi $74.800 \mathrm{~m}^{3}$ dengan jumlah pemakaian awal sebesar $149.600 \mathrm{~m}^{3}$. Biaya yang didapatkan dari penghematan tersebut sebesar Rp..111.3777.200. Berkurangnya pemakaian air maka limbah yang dihasilkan juga berkurang dengan sendirinya. Perkiraan pengurangan limbah cair menjadi sebesar $77.925 \mathrm{~m}^{3}$ per tahun dari sebelumnya sebesar $103.900 \mathrm{~m}^{3}$ per tahun.

Biaya investasi dari implementasi alternatif 1 diperkirakan sebesar $\mathrm{Rp}$. 144.000.000 dan biaya operasionalnya diperkirakan sebesar $\mathrm{Rp} 10.966 .945$.

Berdasarkan hitungan deret seragam, biaya yang dibutuhkan apabila alternatif 1 diterapkan sebesar Rp. 36.856.145 per tahun. Sehingga nilai deret seragamnya sebesar Rp. 62.954.388.

Meskipun teknologi biotray mampu mengurangi kandungan zat kimia yang terdapat pada limbah, namun tingkat perubahannya sangat kecil. Sehingga kandungan zat kimia pada indeks EPI tidak berubah, yang berubah hanya volume limbah cair. Indeks EPI pada alternatif 1 meningkat menjadi 0,77 atau meningkat sebesar 0,31. EPI pada alternatif 1 meningkat sebesar 68\% dari sebelumnya. Produktivitas perusahaan apabila alternatif 1 diterapkan juga meningkat menjadi 136,05\% atau meningkat 0,01\%. 


\section{Alternatif 2}

Kurangnya kapasitas outlet menjadi penyebab banyaknya biaya yang dikeluarkan untuk membeli air, akan lebih bermanfaat apabila air hasil olahan limbah digunakan kembali ketimbang harus dibuang ke sungai. Diperlukan penambahan kapasitas outlet agar mampu menyalurkan air olahan limbah dan mengurangi biaya pembelian air. Apabila tiap 1 outlet sebelumnya berukuran diameter 39,40 inch dan panjang 15 meter dapat menghasilkan $20 \mathrm{~m}^{3} / \mathrm{jam}$, maka alternatif ke 2 adalah dengan cara menambah 1 outlet lagi agar mampu meningkatkan kapasitas debit air menjadi $60 \mathrm{~m}^{3} / \mathrm{jam}$. Estimasi pengeluaran biaya tercantum pada tabel 3 :

\begin{tabular}{cc}
\multicolumn{2}{c}{ Tabel 3 Estimasi Biaya Investasi } \\
\hline Uraian & Harga \\
\hline Biaya pembelian pipa & 143.700 .000 \\
Pembelian flow meter & 15.000 .000 \\
Pompa & 18.000 .000 \\
Biaya instalasi & 50.000 .000 \\
Total & 226.700 .000 \\
\hline
\end{tabular}

Total estimasi biaya investasi sebesar Rp. 226.700.000 dan estimasi biaya operasional sebesar Rp. 10.000 .000 per tahun. Apabila kapasitas outlet yang awalnya hanya $40 \mathrm{~m}^{3} / \mathrm{jam}$ ditambah menjadi $60 \mathrm{~m}^{3} / \mathrm{jam}$, maka volume limbah cair yang dapat digunakan kembali (reuse) sebesar $259.200 \mathrm{~m}^{3} /$ tahun. Dengan begitu air yang dibeli pada Jasa Tirta hanya sebesar $208.022 \mathrm{~m}^{3}$ /tahun atau lebih hemat $112.320 \mathrm{~m}^{3} /$ tahun dibandingkan dengan pembelian air pada tahun 2015. Biaya air yang dihemat apabila harga air Rp. 1.489 per $\mathrm{m}^{3}$ sebesar Rp. 167.244.480.

Berdasarkan hitungan deret seragam, biaya yang dibutuhkan apabila alternatif 2 diterapkan sebesar Rp. 74.344 .310 per tahun. Sehingga nilai deret seragamnya sebesar Rp. 92.900 .170

$$
\begin{aligned}
\mathrm{A} & =\text { Penghematan }-(\text { pengeluaran }+ \text { depresiasi }) \\
& =\text { Rp. } 167.244 .480-(\text { Rp. } 57.174 .310+\text { Rp. } 17.170 .000) \\
& =\text { Rp. } 92.900 .170
\end{aligned}
$$

Meskipun dengan penambahan kapasitas outlet tidak berpengaruh terhadap kandungan zat kimia pada limbah, akan tetapi jumlah volume limbah ikut berpengaruh. Dengan begitu nilai indeks EPI juga meningkat menjadi 0,78 atau meningkat sebesar 0,32 dari sebelumnya dan persentase peningkatan EPI pada alternatif 2 sebesar $69 \%$. Produktivitasnya juga meningkat sebesar 0,020\% menjadi $136,065 \%$ dari sebelumnya.

\section{Memilih Alternatif Solusi}

Pemilihan alternatif solusi dilakukan berdasarkan perhitungan estimasi indeks GPI (Green Productivity Index) terhadap alternatif solusi terpilih. Dengan demikian dapat diketahui perbandingan nilai indeks GPI awal dan indeks GPI terpilih sehingga diketahui peningkatan peforma kinerja lingkungan sebelum dan sesudah alternatif diterapkan. Berikut perhitungan GPI tiap alternatif :

Perhitungan GPI kondisi awal perusahaan alternatif 1 dan alternatif 2 menggunakan rumus GPI (Green Productivity Index):

$$
\text { GPI }=\frac{\text { Tingkat Produktivitas }}{\text { Dampak Lingkungan }}
$$




$$
\begin{aligned}
& \text { GPI Awal }=\frac{136,040 \%}{100 \%}=1,36 \\
& \text { Alternatif } 1=\frac{136,050 \%}{32,43 \%}=4,19 \\
& \text { Alternatif } 2=\frac{136,065 \%}{30,47 \%}=4,47
\end{aligned}
$$

Dari perhitungan GPI dapat diketahui bahwa alternatif 2 memiliki nilai GPI yang lebih tinggi daripada alternatif 1 dan GPI awal perusahaan yaitu sebesar 1,416. Sehingga alternatif ke 2 ditetapkan sebagai alternatif terpilih dan diajukan sebagai usulan untuk perbaikan produktivitas dan kinerja lingkungan.

Tabel 4 Perbandingan Tingkat Produktivitas dan Dampak Lingkungan

\begin{tabular}{ccccc}
\hline No & Keterangan & Tingkat Produktivitas & $\begin{array}{c}\text { Dampak Lingkungan } \\
\text { (Indeks EPI) }\end{array}$ & Persentase \\
\hline 1 & Awal & $136,045 \%$ & 0,69 & $100 \%$ \\
2 & Alternatif 1 & $136,050 \%$ & 0,77 & $88,98 \%$ \\
3 & Alternatif 2 & $136,065 \%$ & 0,78 & $87,59 \%$ \\
\hline
\end{tabular}

\section{Simpulan}

Berdasarkan hasil pengolahan dan analisa, maka dapat diambil beberapa kesimpulan, yaitu tingkat produktivitas perusahaan pada tahun 2012 sampai 2015 berturut-turut yaitu 128,574\%, 132,153\%, 129,610\%, 136,045\%. Total nilai indeks EPI (Environmental Performance Indikator) awal perusahaan adalah 0,46 yang berarti bahwa kinerja lingkungan perusahaan cukup baik karena bernilai positif dan telah memenuhi standar Bapedal tahun 2015. Berdasarkan analisis diagram ishikawa faktor utama yang menjadi penyebab kurang maksimalnya produktivitas adalah masih banyaknya penggunaan air dan limbah cair. Sedangkan limbah cair paling banyak disebabkan oleh mesin kondensor. Selain itu penyebab masih banyaknya biaya pembelian air disebabkan oleh kurang maksimalnya pemanfaat hasil olahan limbah yang terkendala oleh kapasitas outlet. Berdasarkan hasil wawancara terhadap beberapa sumber ahli di PG. Kebon Agung, terdapat 2 alternatif usulan perbaikan bagi perusahaan. Alternatif 1 adalah menggunakan teknologi biotray untuk mengurangi penggunaan air kondensor. Sehingga akan berdampak pada pengurangan volume limbah cair. Alternatif 2 adalah menambah kapasitas outlet agar mampu menampung debit air hasil olahan limbah. Sehingga air hasil olahan limbah dapat digunakan kembali pada proses produksi dan mampu mengurangi biaya pembelian air . Alternatif solusi yang dipilih adalah alternatif 2 yang berdasarkan perhitungan GPI yang merupakan perbandingan produktivitas dan persentase indeks EPI. Produktivitas tahun pertama setelah penerapan alternatif 2 diestimasikan meningkat sebesar 0,32 dari GPI awal perusahaan, sedangkan GPI alternatif 1 hanya meningkat sebesar 0,31 dari GPI awal perusahaan.

\section{Referensi}

[1] L. Yang, "A Study on the Difference of Heterogeneous Firms in Productivity, Production Scale and Production Technology," 2015. 
[2] R. Ortega-Argilés, M. Piva, and M. Vivarelli, "The productivity impact of R\&D investment: are high-tech sectors still ahead?," Economics of Innovation and New Technology, vol. 24, pp. 204-222, 2015.

[3] S. Chen and J. Golley, "Green'productivity growth in China's industrial economy," Energy Economics, vol. 44, pp. 89-98, 2014.

[4] M. A. Darmawan, M. P. I. F. Putra, and B. Wiguna, "Value chain analysis for green productivity improvement in the natural rubber supply chain: a case study," Journal of Cleaner Production, vol. 85, pp. 201-211, 2014.

[5] W. Rusiawan, P. Tjiptoherijanto, E. Suganda, and L. Darmajanti, "Assessment of green total factor productivity impact on sustainable Indonesia productivity growth," Procedia Environmental Sciences, vol. 28, pp. 493-501, 2015.

[6] S.-J. Shin, S.-H. Suh, and I. Stroud, "A green productivity based process planning system for a machining process," International Journal of Production Research, vol. 53, pp. 5085-5105, 2015.

[7] K. WANG, X. MENG, L. YANG, and Y. CHENG, "Heterogeneous Production Technology and Regional Green Total-factor Productivity Growth-An Analysis based on Meta-frontier and China's Provincial Panel Data of 2000-2012," Journal of Beijing Institute of Technology (Social Sciences Edition), vol. 1, p. 004, 2015.

[8] M. Leng and M. C. Ibarra-Vidal, "The Green Solution: Optimizing productivity of bi-substrate microalgae cultures," 2015.

[9] L. Vetter, G. Schuepfer, S. P. Kuster, and M. Rossi, "A Hospital-wide Outbreak of Serratia marcescens, and Ishikawa's "Fishbone" Analysis to Support Outbreak Control," Quality management in health care, vol. 25, p. 1, 2016.

[10] M. Jackson, "Concepts of Productivity," 2015. 